\title{
Diel periodicity of spawning in sciaenids*
}

\author{
G. Joan Holt, Scott A. Holt \& Connie R. Arnold \\ The University of Texas, Marine Science Institute, Port Aransas Marine Laboratory, Port Aransas, Texas 78373, USA
}

\begin{abstract}
Time of day was determined for spawning of several species of sciaenid fishes by examining development stages of eggs collected in estuarine and near-shore plankton samples. Estuarine samples were taken at different times of day and night but newly spawned Cynoscion nebulosus and Bairdiella chrysoura eggs were taken only during a period from just before to 3 or 4 hours after sunset. Sciaenops ocellatus and Mentichirrhus sp. eggs from near-shore Gulf of Mexico samples, taken during the morning, all contained tail-bud stage embryos, indicating evening spawning in these species. It is proposed that evening spawning reduces predation on sciaenid eggs by allowing dispersal of eggs during the night when planktivores may be less active. Overnight dispersal reduced C. nebulosus egg density from $100 \mathrm{~m}^{-3}$ during evening spawning to $1 \mathrm{~m}^{-3}$ the next afternoon. Lower egg densities during the day would reduce egg mortality due to predation. Egg predation experiments showed that predation rates increased with increasing egg density but no difference was found in predation rates between trials run in light and total darkness.
\end{abstract}

\section{INTRODUCTION}

Various selection advantages have been postulated to account for the relatively precise timing of spawning of many fishes. Among these factors are the need to bring large numbers of males and females together, especially in broadcast spawners, so as to maximize fertilization and genetic recombination (Johannes 1978), and to minimize predation on both spawning adults and eggs (Lobel 1978).

Many fish species exhibit diel spawning periodicity. Afternoon spawning (Robertson 1983), sunrise spawning (Pressley 1980, Doherty 1983) and evening spawning (Lobel 1978) have all been reported for tropical reef fishes. Similar variation has been reported among temperate marine and freshwater species (Welsh \& Breder 1923). Although some fish such as striped bass Morone saxatilis (May \& Fuller 1962) and Atlantic mackerel Scomber scombrus (Sette 1943) are reported to spawn throughout both day and night, many marine fish with planktonic eggs spawn only in the evening or night (Ferraro 1980).

The limited published information suggests some sciaenids spawn at night: Bairdiella chrysoura (Kuntz :1914), Cynoscion regalis (Welsh \& Breder 1923, Ferraro

\footnotetext{
- The University of Texas Marine Science Institute Contribution No. 668
}

1980), Cynoscion nebulosus (Tabb 1966), and Seriphus politus (DeMartini \& Fountain 1981). All of the above researchers, except Ferraro, based suspected spawning times on adult breeding activity or reproductive state and not on the occurrence of newly fertilized eggs. Although the latter would provide solid evidence for spawning site and times, the difficulty of identifying sciaenid eggs has precluded its use until recently.

Several years of research in our laboratory on the temperature and photoperiod control of spawning showed that spawning in sciaenids occurred only in the evening. The objective of this work was to determine if naturally occurring populations of sciaenids show a similar diel spawning periodicity.

Dusk or evening spawning may be important in protecting pelagic eggs from predation if (1) darkness reduces feeding by pelagic planktivores and/or (2) low egg densities resulting from overnight dispersal reduce predation during the day (Hobson \& Chess 1978, Robertson 1983). A further aim of our research was to test the assumptions that darkness and egg density affect predation on pelagic eggs.

\section{MATERIALS AND METHODS}

Time of day of spawning (hereafter referred to as spawning time) was based on determining the age of 
eggs collected in the plankton at suspected spawning sites near Port Aransas, Texas. Plankton samples were taken with a $50 \mathrm{~cm}, 505 \mu \mathrm{m}$ mesh net either pulled by boat for $3 \mathrm{~min}$ at the surface or suspended in the tidal current off a pier. Water volume filtered, calculated from flow meter readings, usually varied from 25 to $50 \mathrm{~m}^{3}$. Duplicate tows were taken for preservation and counting. A third sample was retained untreated to provide live eggs which could be hatched in the laboratory for positive identification of species.

Species identification and egg developmental times were determined by bringing live eggs into the laboratory and hatching and raising the young according to procedures developed for red drum Sciaenops ocellatus (Holt et al. 1981). Sciaenid eggs were sorted from other eggs without much difficulty but since all sciaenid eggs looked similar they were separated by size (egg diameter) and raised until the larvae or juveniles could be positively identified (Fable et al. 1978, Johnson 1978, Powles 1980).

Several time series of plankton samples were taken to determine spawning time for spotted seatrout Cynoscion nebulosis. The first series consisted of 5 plankton samples taken over a 24 h period in May 1982 at just before sunset, just after sunset, and at midnight, dawn and noon the following day, After this initial study a series of samples were taken in the evening from before sunset to approximately $3 \mathrm{~h}$ after sunset in September 1982, and May and July 1983. To precisely identify spawning time, the July study consisted of a series of samples taken every 20 to 25 min from 1848 to 2253 h. Spawning data for silver perch Bairdiella chrysoura were obtained from these same collections since silver perch eggs were collected coincidentally with spotted seatrout eggs

Red drum and Menticirrhus sp. (probably $M$. americanus) were collected in plankton samples taken bi-weekly in the morning in the Gulf of Mexico within $1.8 \mathrm{~km}$ of the shore, from August through October 1982, and in samples taken out to $24 \mathrm{~km}$ offshore in October 1983. Sand seatrout Cynoscion arenarius and Atlantic croaker Micropogonias undulatus eggs were occasionally collected in the same samples. Black drum Pogonias cromis, spotted seatrout, silver perch, red drum and Menticirrhus sp. eggs were obtained from both day and night time samples taken during 1982, 1983 and 1984 from a pier in the pass between the Gulf of Mexico and the Aransas-Corpus Christi Bay system. Directional movement of eggs was determined by the direction of the tide in the pass during the sampling.

Silver perch, sand seatrout, spotted seatrout, Menticirrhus sp., Atlantic croaker, black drum and red drum eggs collected in plankton tows were hatched and raised in the laboratory After the egg identifica- tion had been verified, the preserved samples were sorted, counted and egg stages determined.

Additional information was gained from laboratory spawning studies using photoperiod-temperature manipulations to bring about 'natural' maturation and spawning in several sciaenids (described in Arnold et al. 1976, 1977, Arnold 1978). Laboratory-spawned red drum eggs were used to determine the timing of egg developmental stages. Newly spawned silver perch eggs collected from the plankton were also used to verify time of development.

Experiments to evaluate egg predation by fish predators were carried out using laboratory-raised postlarval and juvenile red drum weighing 25 to $500 \mathrm{mg}$ wet weight. Six separate experiments were run, each using red drum of the same age which had not been fed fish eggs previously. No fish were re-used in an experiment. One to 5 fish (depending on size) were placed in 41 tanks containing $30 \mathrm{ppt}$ aerated seawater at $25^{\circ} \mathrm{C}$. Red drum or croaker eggs, spawned in the laboratory, were added to the tanks at densities of 1 to $500 \mathrm{l}^{-1}$; after 2 to $4 \mathrm{~h}$ the fish were removed and the remaining eggs counted. In 2 different tests fish were maintained in total darkness during the experiment. The egg recovery rate in control tanks with no fish was $96 \%$. Summary data were standardized to number of eggs eaten per gram of fish per hour. An analysis of variance for groups with unequal replication was used to test for treatment differences and Duncan's multiple-range test was used to compare individual means (Steel \& Torrie 1960).

\section{RESULTS}

Red drum, Atlantic croaker, sand seatrout and spotted seatrout all spawned in the laboratory during or soon after laboratory-simulated dusk. In 1 case, the times the lights were turned on in the morning and off in the evening were shifted by $3 \mathrm{~h}$, while maintaining a $12 \mathrm{~h}$ light: $12 \mathrm{~h}$ dark photoperiod, and the red drum shifted their spawning time accordingly.

Egg developmental time for red drum is shown in Table 1. Silver perch eggs collected from the plankton and maintained at $25^{\circ} \mathrm{C}$ developed in the same time pattern. Based on these results as well as indirect evidence from field collections, and the very similar developmental times reported by May (1975) for Bairdiella icistia, we assumed that eggs of other sciaenids in our collections developed similarly.

Data from a 24 h sampling of spotted seatrout eggs in May showed that newly spawned eggs were taken in the evening near sunset and no new eggs were collected later at night or in the morning. Developmental stages of new eggs collected live at 2000 h and maintained in the laboratory mirrored the developmental 
Table 1. Sciaenops ocellatus. Development time from fertilization for various stages of laboratory spawned red drum eggs at 25 to $26{ }^{\circ} \mathrm{C}$ and $30 \%$ salinity

\begin{tabular}{|cc|}
\hline Time & Stage \\
\hline $20 \mathrm{~min}$ & 2 -cell \\
$32 \mathrm{~min}$ & 4 -cell \\
$50 \mathrm{~min}$ & 8 -cell \\
$63 \mathrm{~min}$ & 16 -cell \\
$72 \mathrm{~min}$ & 32 -cell \\
$100 \mathrm{~min}$ & Morula \\
$3 \mathrm{~h}$ & Blastula \\
$51 / 2 \mathrm{~h}$ & Gastrula \\
$7 \mathrm{~h}$ & Early embryo \\
$12 \mathrm{~h}$ & Tail-bud stage \\
$17 \mathrm{~h}$ & Tail-free stage \\
$19 \mathrm{~h}$ & Late embryo \\
$21 \mathrm{~h}$ & Begin hatching \\
$24 \mathrm{~h}$ & Most hatched \\
Terminology follows Mansueti \& Hardy (1967) \\
\hline
\end{tabular}

stages of eggs collected in each subsequent plankton tow. Eggs collected at midnight were all in early embryo stage and at $0630 \mathrm{~h}$ were in the tail-bud stage; there were no eggs in the noon collection. In a collaborative study, adult spotted seatrout were collected at the same time and place. Females were running ripe only at dusk, and final oocyte maturation occurred during a $6 \mathrm{~h}$ period before dusk (Thomas et al. 1984).

In plankton samples taken every 20 to $25 \mathrm{~min}$ from before dark until well after dark during July, only well-developed embryos (about to hatch) were collected in the earliest samples (Table 2). Newly fertilized eggs began to occur near sunset, followed in time by later cell-division stages until $2250 \mathrm{~h}$ when the majority of the eggs were in late cleavage stages. Spawning occurred over a period of at least $3 \mathrm{~h}$ but most spawning, evidenced by the frequency of new undifferentiated eggs, was limited to a $1 \mathrm{~h}$ period beginning about half an hour after sunset (Fig. 1).

Table 2. Cynoscion nebulosus. Mean number of spotted seatrout eggs ( $\mathrm{no} .100 \mathrm{~m}^{-3}$ ) in each development stage collected in 2 tows at each time period on July 11, 1983. Sunset occured at $2025 \mathrm{~h}$

\begin{tabular}{|c|c|c|c|c|c|c|}
\hline \multirow[t]{2}{*}{ Time (h) } & \multicolumn{6}{|c|}{ Egg development stage } \\
\hline & New & $1-4$ cell & $8-16$ cell & $32-64$ cell & Morula & Late embryo \\
\hline 1848 & & & & & & 84 \\
\hline 1915 & & & & & & \\
\hline 1946 & 28 & 3 & 3 & & & 78 \\
\hline 2020 & 73 & 125 & & & & 25 \\
\hline 2045 & 583 & 479 & 90 & 15 & 15 & 17 \\
\hline 2123 & 1030 & 700 & 637 & 287 & 18 & \\
\hline 2143 & 1292 & 1437 & 1261 & 990 & 288 & \\
\hline 2221 & 687 & 435 & 1388 & 963 & 985 & \\
\hline 2253 & 228 & 689 & 1800 & 2470 & 5571 & \\
\hline
\end{tabular}

Fig. 1. Diel spawning time for spotted seatrout based on number of new eggs in the sample. ss $=$ time of sunset

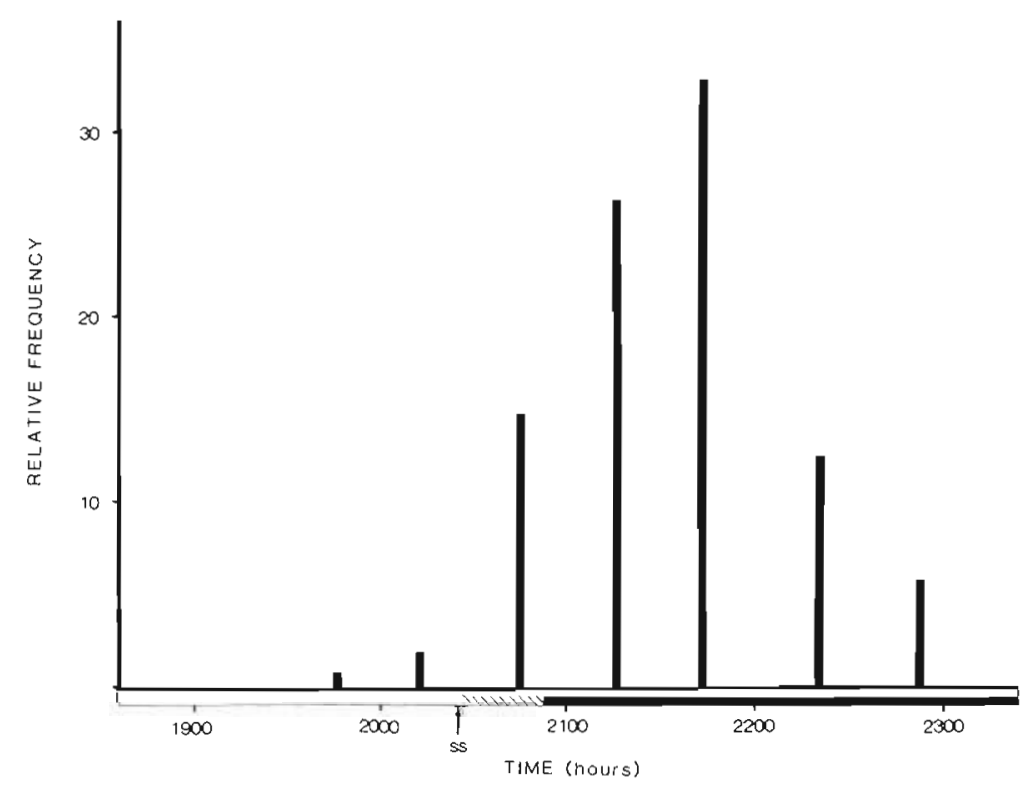


In 3 other series of samples taken from before dark to several hours after dark, more than $50 \%$ of the new eggs were collected during the period $1 / 2 \mathrm{~h}$ before sunset to $1 \frac{1 / 2}{h}$ after sunset (Table 3 ). Samples taken at dawn contained only embryo stage eggs.

Silver perch and spotted seatrout eggs co-occurred in most of the plankton samples; the silver perch eggs were consistently smaller. Silver perch spawning occurred over a longer period of time than spotted seatrout (Table 4) with some spawning commencing earlier than spotted seatrout and continuing later in the evening. However, silver perch never spawned outside this relatively large 'window' around sunset. On 15 other dates from April through September, samples taken at various times throughout the day and night contained spotted seatrout and silver perch eggs that were in a predictable stage of embryo development based on spawning near sunset the previous day. No newly fertilized eggs were ever collected after midnight or before $1800 \mathrm{~h}$. Eggs of both species were only collected in the bay or on ebb tide in the pass, indicating both are estuarine spawners. Early-stage eggs of spotted seatrout were consistently collected near or over seagrass beds.

Spawning information on several other sciaenids has been developed by back-calculating from eggs collected the day following spawning. In samples taken bi-weekly in late summer through fall (water temperature 27 to $30^{\circ} \mathrm{C}$ ) red drum embryos were always in the tail-bud stage at $1000 \mathrm{~h}$ and Menticirrhus sp. in late embryo at that time. Based on known development time of red drum eggs in the laboratory, these eggs were spawned about 12 to 14 h earlier. Red drum eggs collected at night between 2200 and $2400 \mathrm{~h}$ ranged from early cell division to morula stage, which con-
Table 4. Bairdiella chrysoura. Mean number of silver perch eggs (no. $100 \mathrm{~m}^{-3}$ ) in each developmental stage collected in 2 tows at each time period on July 11, 1983. Sunset occured at 2025

\begin{tabular}{|rrrrr|}
\hline \multirow{2}{*}{ Time $(\mathrm{h})$} & \multicolumn{4}{c|}{ Egg developmental stage } \\
& New & 2-16 cell & 32-morula Late embryo \\
\hline 1848 & 144 & 254 & 45 & 387 \\
1915 & 18 & 101 & 55 & 524 \\
1946 & 96 & 83 & 46 & 132 \\
2020 & 97 & 352 & 74 & 133 \\
2045 & 646 & 485 & 15 & 7 \\
2123 & 1192 & 2724 & 571 & 0 \\
2143 & 1054 & 6696 & 2835 & 0 \\
2221 & 1316 & 4632 & 4761 & 0 \\
2253 & 2351 & 9030 & 19027 & 0 \\
& & & & \\
\hline
\end{tabular}

firmed that spawning took place 1 or 2 h earlier, near 2000 to $2200 \mathrm{~h}$.

The estimated spawning times for 7 species of sciaenids shown in Fig. 2 are based on: (1) precise time series data for egg development of silver perch and spotted seatrout; (2) numerous data from egg collections over a narrow diel time period (0930 to $1100 \mathrm{~h}$ ) for red drum and Menticirrhus sp.; (3) a few data collections for sand seatrout, black drum and Atlantic croaker. Diel spawning times for the last 5 species may represent the time of peak spawning for those species but not the range of spawning times. Where more detailed information is known, such as for silver perch, spotted seatrout, and red drum in the laboratory, the range of spawning time is limited to about 4 to $5 \mathrm{~h}$.

Spawning in the Gulf, within a few km of the pass, was indicated for red drum and several other sciaenids. Menticirrhus sp. eggs were collected along with red

Table 3. Cynoscion nebulosus. Relative frequency of spotted seatrout egg stages as a function of time before (-) or after sunset ( + ) (h) for 3 collection dates

\begin{tabular}{|c|c|c|c|c|c|}
\hline \multirow[t]{2}{*}{ Date } & \multirow[t]{2}{*}{ Time $(\mathrm{h})$} & \multicolumn{4}{|c|}{ Egg stage } \\
\hline & & New & $2-16$ & 32-morula & Embryo \\
\hline 11 May 1983 & $\begin{array}{l}-1 / 2 \\
+1 / 2 \\
+1 \\
+13 / 4 \\
+21 / 2\end{array}$ & $\begin{array}{c}11.8 \\
67.3 \\
16.9 \\
4.0 \\
0\end{array}$ & $\begin{array}{r}11.3 \\
13.0 \\
64.1 \\
10.1 \\
1.5\end{array}$ & $\begin{array}{r}0.5 \\
4.5 \\
48.8 \\
43.0 \\
3.0\end{array}$ & 100 \\
\hline 26 May 1983 & $\begin{array}{c}-1 / 2 \\
0 \\
+3 / 4\end{array}$ & $\begin{array}{r}79.6 \\
19.9 \\
0.4\end{array}$ & $\begin{array}{l}70.0 \\
30.0\end{array}$ & 100.0 & \\
\hline 1 Sep 1982 & $\begin{array}{l}-1 / 3 \\
+1 \\
+11 / 4 \\
+21 / 4 \\
+12\end{array}$ & $\begin{array}{r}15.9 \\
35.1 \\
47.7 \\
1.3\end{array}$ & $\begin{array}{l}58.1 \\
41.9\end{array}$ & $\begin{array}{l}24.5 \\
75.5\end{array}$ & 100 \\
\hline
\end{tabular}


ESTIMATED SPAWNING TIME

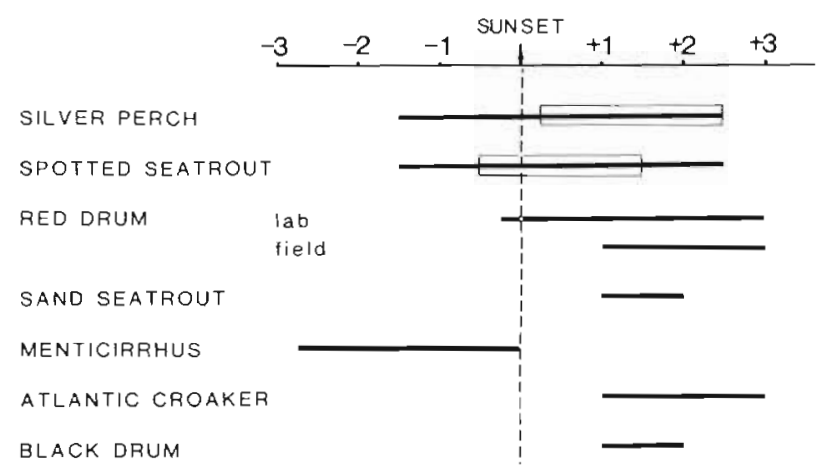

Fig. 2. Estimated range (solid bars) and maximum intensity (open bars) of spawning relative to time of sunset for 7 species of sciaenids

drum eggs $1.8 \mathrm{~km}$ offshore and in the pass on flood tides from August through October. Atlantic croaker eggs were collected in plankton tows $24 \mathrm{~km}$ offshore in October, and sand seatrout were taken on flood tides in the pass in August.

Results of egg-eating experiments showed a significant increase in the relative number of eggs eaten with an increase in egg density but it could not be shown that darkness reduced feeding on eggs (Table 5). There was no consistent difference between the number of eggs eaten in light versus dark over all densities. At low densities ( 1 and 10 eggs $1^{-1}$ ) fish often ate no eggs, whereas at higher densities fish always ate some of the eggs even in complete darkness. One small $(20 \mathrm{~mm})$ fish ate 143 of 500 eggs during a period of $2 \frac{1}{2} \mathrm{~h}$. The lack of difference in egg consumption between light and dark experiments allowed us to combine these data and add other light-only experi- ments to obtain a more comprehensive test of the effect of egg density on feeding rate (Table 6). Duncan's multiple range test showed that at egg densities of 100 and 500 eggs $1^{-1}$ significantly more eggs were eaten than at lower densities.

\section{DISCUSSION}

Both direct and indirect evidence from our research in the laboratory and field, combined with published data on other sciaenids, lead us to theorize that spawning at dusk is a general reproductive strategy for temperate sciaenids. Further evidence for an entrained diel spawning cycle is that it can be manipulated in the laboratory. Information on spawning time has previously been reported for only a few sciaenids, but they also suggest evening or night spawning (Kuntz 1914, Welsh \& Breder 1923, Hildebrand \& Cable 1930, Ferraro 1980 ). Our findings confirm previous reports, add new information on 5 more species, and lead us to propose the generality of diel spawning at dusk for sciaenids.

Maintaining a diel spawning periodicity would be an advantage to 'broadcast' spawners such as sciaenids by guaranteeing that a large number of fish would be in spawning condition at the same time, thereby maximizing fertilization of the large number of eggs released into the water column. Dawn or daylight spawning occurs in several species that have visual courtship displays (Middaugh 1981, Doherty 1983) but sciaenids primarily use sound (drumming of the air bladder) for courtship, especially in the final stages, so spawning is not dependent on light. Mok \& Gilmore (1983) found that maximum sound production for 3

Table 5. Analysis of egg eating experiments comparing differences in egg consumption among different egg densities and between trials run in the light and in total darkness

\begin{tabular}{lrrrrr|}
\hline & Sum of squares & DF & Mean square & F \\
\hline Density & 30287.243 & 3 & 94.080 & 9.728 & .001 \\
Light & 94.080 & 1 & 94.080 & .091 & .767 \\
Density/light & 2728.836 & 3 & 909.612 & .876 & .474 \\
Error & 16605.455 & 16 & 1037.841 & \\
\hline
\end{tabular}

Table 6. Analysis of egg consumption at various densities. Means are number of eggs eaten per gram of fish per hour. ANOVA of means was highly significant $(\mathrm{f}=12.190 \mathrm{df}=6, \mathrm{P}<0.001$ ). Underlining connects means which are not significantly different (Duncan's multiple range test; $P=0.05$ )

\begin{tabular}{ccccccc}
\hline 1 & 10 & Egg density (1-1) & & 100 & 500 \\
\hline 0.143 & 4.273 & 15 & 25 & 50 & 95.000 & 388.000 \\
\hline
\end{tabular}


sciaenids occurred between 1700 and $2200 \mathrm{~h}$ and proposed that this was their primary spawning time.

Several factors have been suggested as selective advantages for dusk or night spawning in fishes. These factors, which might account for dusk rather than dawn spawning, include: avoiding deleterious effects of sunlight on eggs (Perlmutter 1961), limiting predation on the adults (Hobson \& Chess 1978), and reducing predation on eggs (see Robertson 1983 for review). The first 2 factors are not significant in this case. Since sciaenid eggs take at least 18 to $36 \mathrm{~h}$ to hatch (depending on the temperature), and are found in the upper $1 / 2 \mathrm{~m}$ of the water column, they are exposed to sunlight for some period of time without adverse effects. Moreover, the newly fertilized eggs of daytime spawning fishes with pelagic eggs are apparently unaffected by visible light. Predation on adult sciaenids is generally not a problem since they are as large as or larger than most piscivorous predators in their community.

We suggest that mass spawning at dusk in sciaenids is an adaptation that reduces egg loss due to predation. Several authors have suggested that spawning at dusk or in the evening reduces egg predation because planktivores are inactive during this time (Lobel 1978, Ferraro 1980, Robertson 1983). Hobson \& Chess (1978) reported that eggs were insignificant in the gut contents of nocturnal planktivores despite a 7 -fold increase in egg density at night. They suggested the relative invisibility of eggs at night was the reason for the difference. Since our experiments show fish can find and eat eggs in total darkness, the difference may be due to changes in feeding patterns of zooplanktivores at night (Hobson 1974).

We have found that juveniles of many species of fish will readily consume pelagic eggs fed to them in an aquarium. Several species in the following families enthusiastically feed on sciaenid eggs: Carangidae, Lutjanidae, Sciaenidae, Pomacentridae, Bleniidae and Balistidae. In most cases as soon as the eggs are located by the fish they are systematically eaten until all are consumed. Many of these species, especially the carangids, form foraging groups which can be seen feeding in the surface water during the day. These small fishes may confine their activity to daylight in response to a decrease in their ability to detect predators at night.

It has often been hypothesized that dusk or night spawning reduces egg predation but few data have been presented to confirm this. Implicit in this hypothesis are the assumptions that low egg densities will result from overnight dispersal, and that egg predation will be reduced at these low egg densities. We found that spotted seatrout eggs were reduced from a high of $100 \mathrm{~m}^{-3}$ during spawning to less than $1 \mathrm{~m}^{-3}$ in the afternoon; a 100-fold reduction in egg density after
$20 \mathrm{~h}$ of wind and tide dispersal. These numbers are conservative because at the spawning site eggs are probably much more numerous than we found in plankton samples. For example, 1 spotted seatrout can produce at least $1 \times 10^{4}$ eggs per spawn (Arnold 1978) and since many fish are involved in a single spawning episode, the density of eggs during fertilization could be very high. Red drum have an even higher fecundity, producing an average of $3 \times 10^{5}$ eggs per fish per spawn (Arnold 1978) yet the maximum number we collected in the Gulf of Mexico, the morning following red drum spawning, was $5 \mathrm{~m}^{-3}$ and the average collection was less than $0.1 \mathrm{~m}^{-3}$. Thus overnight dispersal does greatly reduce egg density.

Our laboratory experiments showed egg predation to be positively correlated with egg density. Hence, the low egg densities which typically result from overnight dispersal of sciaenid eggs would protect those eggs from predation. To confirm the adaptive significance of dusk spawning in sciaenids, the feeding behavior of potential egg predators must be known. If egg predators are not active at dusk or after dark, then spawning at this time will result in overnight dispersal and reduction of egg density and a corresponding reduction in predation.

Acknowledgements. We thank Liz Young Abel and Robbin Rogers for diligently and patiently identifying, sorting and counting fish eggs and John Cullen, Donald E. Wohlschlag and 3 anonymous reviewers for critically reading our manuscript. This work was funded in part by Texas A\&M Sea Grant, United States Department of Commerce, under Grant NA83AA-D-00061, and in part by awards from the Sid W. Richardson Foundation and the Caesar Kleberg Foundation for Wildlife Conservation.

\section{LITERATURE CITED}

Arnold, C. R. (1978). Maturation and spawning of marine finfish. In: Sindermann, C. J. (ed.) Proc. of the 7 th U.S. Japan meeting on aquaculture, marine finfish culture, Tokyo, Japan. NOAA Tech. Rep. NMFS 10, p. 25-27

Arnold, C. R., Lasswell, J. L., Bailey, W. H., Williams, T. D., Fable, W. A., Jr. (1976). Methods and techniques for spawning and rearing spotted sea-trout (Cynoscion nebulosus) in the laboratory. Proc. a. Conf. SEast. Ass. Fish \& Wildlife Agency 30: 167-178

Arnold, C. R., Bailey, W. H., Lasswell, J. L., Williams, T. D., Johnson, A. (1977). Laboratory spawning and larval rearing of red drum and southern flounder. Proc. a. Conf. SEast. Ass. Fish \& Wildlife Agency 31: 437-440

DeMartini, E. E., Fountain, R. K. (1981). Ovarian cycling frequency and batch fecundity in the queenfish Seriphus politus: attributes representative of serial spawning fishes. Fish. Bull. U. S. 79: 547-560

Doherty, P. J. (1983). Diel, lunar and seasonal rhythms in the reproduction of two tropical damselfishes: Pomacentrus flavicauda and P. wardi. Mar. Biol. 75: 215-224

Fable, W. A., Williams, T. D., Arnold, C. R. (1978). Description of reared eggs and larvae of the spotted sea trout, Cynoscion nebulosus. Fish. Bull. U.S. 76: 65-71 
Ferraro, S. P. (1980). Daily time of spawning of 12 fishes in the Peconic Bays, New York. Fish Bull. U. S. 78: 455-464

Hildebrand, S. F., Cable, L. E. (1930). Development and life history of fourteen teleostean fishes at Beaufort, N. C. Bull. U.S. Bur. Fish. 46: 382-488

Hobson, E. S. (1974). Feeding relationships of teleostean fishes on coral reefs in Kona, Hawaii. Fish. Bull. U. S. 72 915-1031

Hobson, E. S., Chess, J. R. (1978). Trophic relationships among fishes and plankton at Enewetak Atoll, Marshall Islands. Fish. Bull. U.S. 76: 133-153

Holt, J., Godbout, R., Arnold, C. R. (1981). Effects of temperature and salinity on egg hatching and larval survival of red drum Sciaenops ocellata. Fish. Bull. U. S. 79 (3): 569-573

Johannes, R. E. (1978). Reproductive strategies of coastal marine fishes in the tropics. Environ. Biol. Fish. 3: 65-84

Johnson, G. D. (1978). Family Sciaenidae. In: Development of fishes of the mid-Atlantic Bight: an atlas of egg, larvae and juvenile stages. U.S. Dept. Interior, Fish. Wildl. Service, Biol. Serv. Program, Vol 4: 169-250

Kuntz, A. (1914). The embryology and larval development of Bairdiella chrysoura and Anchovia mitchilli. Bull. U.S. Bur Fish. 33: 1-19

Lobel, P. S. (1978). Diel, lunar, and seasonal periodicity in the reproductive behavior of the Pomacanthid fish, Centropyge potteri, and some other reef fishes in Hawaii. Pacif. Sci. 32: 193-207

Mansueti, A. J., Hardy, J. D. (1967). Development of fishes of the Chesapeake Bay region: an atlas of egg, larval and juvenile stages. University of Maryland Inst. Nat. Resour., p. $1-202$

May, R. C. (1975). Effects of temperature and salinity on fertilization, embryonic development and hatching in Baridiella icistia (Pisces: Sciaenidae), and the effect of parental salinity acclimation on embryonic and larval salinity tolerance. Fish. Bull. U. S. 73: 1-22

May, O. D., Jr., Fuller, J. C., Jr. (1962). A study on striped bass egg production in the Congaree and Wateree Rivers. S. C Wildl. Resour. Dept. Div. Game, p. 1-28
Middaugh, D. P. (1981). Reproductive ecology and spawning periodicity of the Atlantic silverside, Menidia menidia (Pisces: Atherinidae). Copeia 1981: 766-776

Mok, H., Gilmore, R. G. (1983). Analysis of sound production in estuarine aggregations of Pogonias cromis, Baridella chrysoura and Cynoscion nebulosus (Sciaenidae). Bull. Inst. Zool. Academia Sinca 22: 157-186

Perlmutter, A. (1961). Possible effect of lethal visible light on year-class fluctuations of aquatic animals. Science 133: $1081-1082$

Powles, H. (1980). Description of larval silver perch, Bairdiella chrysoura, banded drum Larimus fasciatus, and star drum, Stellifer lanceolatus (Sciaenidae). Fish. Bull. U.S. 78: $119-136$

Pressley, P. H. (1980). Lunar periodicity in the spawning of yellowtail damselfish Microspathodon chrysoura. Environ. Biol. Fish. 5: 153-159

Robertson, D. R. (1983). On the spawning behavior and spawning cycles of eight surgeonfishes (Acanthuridae) from the Indo-Pacific. Environ. Biol. Fish. 9: 193-223

Sette, O. E. (1943). Biology of the Atlantic mackerel (Scomber scombrus) of North America. Part I. Early life history including growth, drift, and mortality of the egg and larval populations. Fish. Bull. U. S. 50: 149-237

Steel, R. G. D., Torrie, J. H. (1960). Principles and prodedures of statistics. McGraw-Hill, New York

Tabb, D. C. (1966). The estuary as a habitat for spotted seatrout, Cynoscion nebulosus. In: Smith, R. F. (ed.) A symposium on estuarine fisheries. AM. Fish. Soc. Spec. Publ. No. 3, p. 59-67

Thomas, P., Brown, N. J., Arnold, C. R. (1984). Annual and diurnal rhythms of circulating steroids in wild-caught mature female spotted seatrout (Cynoscion nebulosus). Am. Zool. 24: 69A

Welsh, W. W., Breder, C. M., Jr (1923). Contributions to life histories of sciaenidae of the eastern United States coast. Bull. U. S. Bur Fish. 48: 41-117 